\title{
Friends Doing Business. An Explorative Longitudinal Case Study of Creativity and Innovation in an Italian Technology- Based Start-Up
}

\section{Alessandra Tognazzo ${ }^{1}$ and Paola Angela Maria Mazzurana ${ }^{2}$}

\begin{abstract}
With a process perspective based on a framework derived from several disciplines, we theoretically discuss how friendship dynamics in founding teams may affect a business. We develop a conceptual model that considers the different nature of exchanges in business and friendship, which may serve as a useful starting base for future investigation (in the Appendix we report some measures of friendship). We then examine an exemplary case. We focus on group cohesiveness (a proxy for friendship), decision-making, and organization of an Italian technology-based firm's founding team over time and explore the process of generating creative ideas and implementing innovation. Our speculative findings show that chaos does not necessarily favor creativity and innovation: while low group cohesiveness leads to disorganization because business norms prevail over friendship ones, high group cohesiveness creates structure in the organization that sustains the generation of creative outcomes by enhancing the role of friendship norms in decision-making. We explain this finding in the light of the principle of reciprocity of exchanges.
\end{abstract}

Keywords: spin-offs; reciprocity; friendship; group-cohesiveness; creativity; innovation.

\section{INTRODUCTION}

To be successful new entrepreneurs must be innovators-creative, idealist, and visionary. In most new technology-based firms the founding team has a major role in this process, especially given the limited size of the organization (Amason \& Sapienza, 1997; Cesaroni, Minin \& Piccaluga, 2005;

\footnotetext{
1 Alessandra Tognazzo, Ph.D., University of Padova, Department of Economics and Management "Marco Fanno", Via del Santo 33, I-35123 Padova; e-mail: alessandra.tognazzo@unipd.it.

2 Paola Angela Maria Mazzurana, Adjunct Professor, Department of Economics and Statistics, University of Udine, Via Tomadini 30/a, Udine, I-33100; e-mail: paola.mazzurana@uniud.it.
} 
Klotz, Hmieleski, Bradley \& Busenitz, 2014). Interestingly, a lot of literature has emerged about families and innovation within businesses, and scholars in this literature showed that family dynamics do impact on innovative processes and outcomes (e.g., De Massis, Frattini \& Lichtenthaler, 2013; Kammerlander et al., 2015). Whereas relatives are designated by blood or legal ties, friends are selected, so friendship is a unique form of voluntary intimate relationship. Furthermore, friendship is a relatively uninstitutionalized relationship without standard rituals, norms or nomenclature to guide the partners. Yet, friendship choices are not wholly fortuitous, nor is amicable behaviour unscripted (Allan, 1989). Also, friendship evolves over time and it is the process of living from day-to-day that shapes friendship patterns (Blieszner \& Adams, 1992; Hays, 1988). Some friendships are based on routine, repeated, and predictable interactions, while others are formed after chance meetings. The individual's social and psychological characteristics set the stage for the types of relationships that can emerge (Adams \& Blieszner, 1994). Sociological research about groups of artists shows how friendship fosters creativity in these collaborative circles. Farrell (2001) notes that the figure of the lone genius is not always accurate in this context and that extraordinary creativity is often the result of successful collaboration among peers who develop an intense friendship and work together for an extended period. Farrell argues that such work is spurred by a set of enabling social dynamics that work to support, encourage, and stimulate creativity among members of the group (Farrell, 2001; Corte, 2013).

Despite the widespread occurrence in new ventures of friends doing business together, research in management devotes virtually no attention to friendship and to how it might be related to business creative outcomes. Research in laboratory and organizational settings has focused on how creativity and innovation can be fostered in work-groups (or work-teams) focusing on methods like idea generation, brainstorming (e.g., Paulus \& Yang, 2000; West, 2002) or creative synthesis (Harvey, 2014). All these studies underline the importance of individuals' cognitive resources like creative thinking skills, social resources inherent in group composition and dynamics, and environmental resources that support autonomy and motivation. However, this stream has focused on creative processes and outcomes generated by teams and groups of workers, not company owners. Moreover, leadership researchers have proposed that leaders' styles and behaviours might be transformational and promote change among followers and employees, and also in start-ups founding teams (e.g., Chen, 2007). However, these studies do not devote attention to the quality of the relationships 
among the founding team members. Also, psychologists and sociologists have focused on the relation between the group of friends and the individual in various contexts, like artists and classrooms (e.g., Farrell, 2001; Starko, 2013), but the issue of business still remains underexplored in this literature.

In this article, we chose to focus on analyzing how friendship impacted on the inception and development of one Italian start-up. This start-up is not an "exceptional" case, it is "one of the many", but we have followed its story since the founders were a group of friends, so well before venture founding. After observing them for eight years, we realized that friendship has a meaningful impact on creativity and innovation processes. Not only friends generated the idea of a venture and implemented it by founding one, but also friendship is strictly related to internal organizational dynamics and has a major influence on decision-making processes that impact on how creative ideas may become implemented innovations (e.g., products, etc). This research is largely explorative - and to some extent "intuitive" in nature, and includes both informally collected information (which derives from observing the start-up over its development) and purposefully collected evidence (though interviews and direct observation).

Our aim here is twofold. First, we want to shed light on the underexplored issue of friends doing business together. We review some theoretical perspectives that might be applied to the issue of friendship as an element that affects individuals' and groups' creative activity in the business context. Given that virtually no literature has specifically considered this aspect in the business context, we aim to bring together theoretical perspectives belonging to several research streams and provide the basis for future investigation about friends doing business together. Second, we explore how friendship can sustain organizational creativity and innovation, focusing in particular on decision-making processes. In line with a recent call for additional research on the relationship between entrepreneurs' group dynamics and innovative processes (Baron \& Tang, 2011; Brockman, Rawlston, Jones \& Halstead, 2010), our paper aims to shed light on an interesting phenomenon which we hope will stimulate the attention of scholars.

In the following sections, we consider the definition of creativity and innovation and review several streams of literature about friendship. Then, we describe the main findings and propositions. Finally, we present conclusions and directions for further research. 


\section{THEORETHICAL BACKGROUND}

\section{When creativity spurs innovation: Is friendship a missing link?}

In this paragraph, we first articulate the definitions of creativity and innovation based on the managerial literature. Then, we review what psychological studies report about friendship and we integrate the sociological viewpoint. Also, we propose a model that may serve as a basis for future investigation of friends in business.

\section{Creativity and innovation: The managerial process approach}

Theoretical work in the management field has focused on how to define the phases of innovation processes. Models that address creativity (Crossan \& Apaydin, 2010; Woodman et al., 1993) define innovation as an outcome of creativity which characterizes the even broader construct of organizational change and thus consider creativity and innovation as consecutive phases.

Creativity at the individual level is usually defined as an approach to work that leads to the generation of novel and appropriate ideas, processes, or solutions (Amabile, Conti, Coon, Lazenby \& Herron, 1996; Ford, 1996; Shalley, 1991). The appropriateness and novelty of an idea, process, or solution depend on the context: in order to be considered creative and innovative, these outputs must be unique in some way. Innovation can be defined as the production or adoption, assimilation, and exploitation of a value-added novelty, renewal or enlargement of a products or service, development of a new method of production, and/or establishment of new management systems or markets (Crossan \& Apaydin, 2010). Innovation, then, is both a process and an outcome.

The characteristics of creativity and innovation differ in the required degree of novelty and social interaction, as creativity results in something novel, while innovation can be based on ideas that are adopted from previous experience or other organisations. Moreover, innovation is primarily a social process, whereas creativity is at least to some extent an individual cognitive process (Anderson \& King, 1993).

In this paper, we take a process perspective. We define creativity as the first step before innovation-the generation of good, valuable ideas that could (or could not) be actualized as innovations (e.g., new products, services, or processes), while innovation as the implementation and development of ideas - the introduction and application of new ideas to a relevant group. These definitions are logical. However, these phases in organizations are not always consequential, as recent meta-analysis shows (Sarooghi, Libaers $\&$ Burkemper, 2015). The generation of creative ideas requires favourable 
conditions to become actual innovation. Indeed, Sarooghi et al. (2015) show that the relationship between creativity and innovation is stronger for large firms, process innovations, and low-tech industries relative to small firms, product innovations, and high-tech industries. In other words, it appears that high-tech start-ups are disadvantaged in terms of transforming creative ideas into innovation. The "why" question still remains open to possible explanation. Given that little work has been done on how group dynamics affect these two consequential phases (Rank, Pace \& Frese, 2004), we speculate that friendship dynamics have a role in this link.

Indeed, it is also interesting to note that, even if the management literature suggests that there are cognitive, social and environmental resources that may enhance group creativity, the empirical evidence is equivocal on how a group may affect creativity. For instance, interaction is necessary to provide access to other members' cognitive resources, but it is challenging for group members and depletes their own cognitive resources for idea generation (Diehl \& Stroebe, 1987); diversity is expected to provide more varied input, but diverse groups sometimes underperform homogeneous groups on creative tasks (Harvey, 2013); and a supportive environment is expected to enhance creativity, but constrained task environments sometimes also promote creativity (Hoegl, Gibbert \& Mazursky, 2008). Thus, we speculate that friendship is an underexplored element that might impact on business processes and outcomes, such as innovation and creativity.

\section{Friendship: The evolutionary psychological approach}

Interest in friendship relations significantly predates the earliest psychological investigation of the topic as philosophers have elucidated conceptual and theoretical considerations of friendship for well over twenty centuries. Hebrew proverbs remind us that being friendless is akin to living life with only one hand, whereas Chinese proverbs urge tolerance of our friends' frailties in lieu of removing these flaws with a hatchet. Greek and Roman philosophers in antiquity considered friendship to be a requisite aspect of moral and political philosophy and developed theories of friendship to support their positions (Aristotele cited by Ross, 1925). The empirical investigation of friendship is quite recent and range from definitions of friendship and its components (Sullivan, 1953) to investigations of the importance of peer and friendship relations for child development (e.g., Parker \& Asher, 1987).

Sullivan's (1953) contends that friendships emerge in the preadolescent period, when the need for acceptance, fulfilled by participation in general peer group interactions in the juvenile era, shifts to the need for interpersonal intimacy. He deemed friendship a collaborative relationship, and that friends 
are sensitive to the needs of one another and seek mutual satisfaction. So, friendship fulfils a fundamental human need for social interaction (Baumeister \& Leary, 1995; Demir \& Davidson, 2013).

Friendship is a voluntary interdependence between two individuals that includes the experience and satisfaction of various provisions (intimacy, support and self-validation) to varying degrees (Hays, 1988; Demir et al., 2014). However, friendship is a mixed blessing such that it also involves conflict (Berndt \& McCandless, 2009; Solano, 1986). Indeed, scholars who explore group dynamics distinguish group cohesiveness from friendship, highlighting that group cohesiveness is related to social attraction and solidarity, while friendship may fragment and disrupt the group (Hogg \& Hains, 1998).

Friendship literature also highlights the fact that friendship dynamics evolve over time. Friendships have beginnings, when partners become acquainted; middles, when solidarity and other features increase/decrease/ fluctuate or remain stable; and sometimes, endings due to a variety of reasons (Blieszner \& Adams, 1992; Hays, 1988). Any movement from one friendship phase to another might be deliberate or might occur by chance. In young adulthood friendship and romance relationships may also be intertwined (Collins \& van Dulmen, 2006).

This literature is largely focused on the individual and the evolution of the human being and virtually no attention has been devoted to how friendship might impact on business dynamics. We propose here one model of investigation based on the notion of exchanges that can be a useful base for future research aiming to explore friendship and business together.

\section{Exchanges in friendship and business: Integrating different logics}

Both friendship and business relationships are two different forms of social relationships. Social relationships are characterized by exchanges and these exchanges can be governed by different logics.

Social psychologists refer to exchange of resources as the social events which are most relevant to relationship formation and maintenance. Resources can be anything from attention and approval to food, clothing, and money (Foa, 1973).

Today, organizations survive because their exchanges are governed by the principle of reciprocity. The fact that the balance sheet may includes debts (or credits), materially shows the existence of this principle because they owe something to someone (or vice versa). If organizations do not respect the norms of reciprocity they simply fail (i.e. cease to exist). For instance, even a non-for-profit organization that does not pay its debts or which is not able to give back to the community a "social value" that justifies 
its existence ceases to exist. This idea is highly in line with those traditional theories that see organizations as a nexus of contracts (e.g., Coase, 1937; Jensen \& Meckling, 1976). Therefore, all business relationships (both forprofit and non-for-profit) are by definition exchange oriented ones, where exchange may be in various form (material goods such as money; behaviours such as work; or intangible values, such as social recognition, legitimacy, support etc.). In other words, business relationships are exchange-oriented relationships and as such, are characterized by norms of reciprocity.

Ideally, friendship relationships are non-exchange oriented ones (i.e. friends do something independently of receiving something back). This concept mirrors the idea of "ideal altruism" (where parties involved in a transaction don't expect anything back). This means that friendship relationship should not be governed by the principle of reciprocity. However, we commonly assume that friendship is reciprocal in nature to the point that even the very nature of the relationship is influenced by this: if we say "Giulia is "my friend," the implication is that Giulia also thinks of me as a friend. In general, reciprocity is one of the expectations about affective relations (e.g., Laursen, 1993). What is different is that generally these affective elements are highly subjective and therefore they are hard (if not impossible) to measure, therefore these relationships are to some extent characterized by inequality of what is exchanged (e.g., I give you a hug, you give me a kiss... but what is the value of that hug or that kiss?).

In James Coleman's seminal essay about social capital (see next paragraph), one important feature of social capital is the reciprocity of expectations and norms (Coleman, 1988); similarly, friendships that are more reciprocal are likely to be more emotionally supportive as well as a superior resource compared to friendships that are less reciprocal.

Figure 1 is a representation of the above-mentioned concept. When relationships involve exchanges, the principle of reciprocity may operate according to different intensities, which is why we represented it here on a continuum. Generally, in an exchange oriented relationship - which typically characterizes how companies operate - business norms presume full equality of exchange. While in non-exchange oriented relationships - that are present in amicable relationships - friendship norms imply a different evaluation of what is an "equal" exchange to the point that this exchange might also become irrelevant.

This simplified model may explain the friction generated by integrating friendship with business norms. Given that exploring these kinds of dynamics and interactions requires more than an exploratory research work, we hope this may provide a basis for further inquiry in this context. 
Governing principle of exchanges in relationships

Non-exchange oriented relationships

Friendship Norms
Exchange oriented elationships

Business Norms

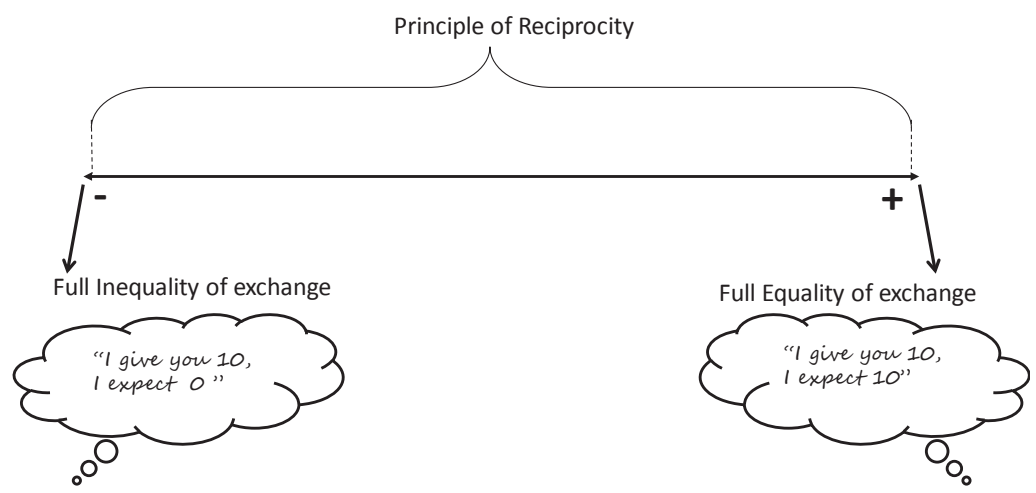

Figure 1. Reciprocity in business and friendship

\section{Friendship and group cohesiveness: A prosocial approach}

In this article, we focus on a group of friends governed by norms of prosocial reciprocity, where by prosocial we mean that people ought to return favours ("Do unto others") rather than aggressive reciprocity that permits retaliation ("An eye for an eye"). Even if we acknowledge that this is a partial view of friendship dynamics, this "bounded" definition helped us guide our exploratory study. Group cohesiveness may parallel the concept of "friendship governed by prosocial reciprocity" because as mutual trust, and closeness among individuals increase, both friendship and group cohesiveness also increase. A cohesive group is one that sticks together, whose members are bonded to one another, and to the group. Cohesiveness is often accompanied by feelings of solidarity, harmony, and commitment (Mudrack 1989a). Mullen and Copper (1994) suggest that group cohesion is a 'lubricant' that minimizes the friction from the human 'grit' in the system. The most widely accepted definition of group cohesion describes it as "forces which are acting on the members to stay in a group" (Festinger, 1970: 274).

Psychology studies that focus specifically on the relationship between group cohesiveness and creativity, sustain the ideas that cohesion is associated with high levels of conformity and commitment to prior courses of action, a lack of openness to new information, and interference with a group's ability to use information fully, which prevents the generation of 
new ideas. However, experimental evidence (Craig \& Kelly, 1999) shows that groups in situations with high levels of task and interpersonal cohesion exhibit high levels of creativity. Studies on collaborative circles and scientific collaborations also support this idea (Farrell, 2001; Levine \& Moreland, 2004).

In sum, even though there is some empirical evidence in favour of the positive effect of group cohesiveness on group creative performance, there are also theoretical arguments in favour of a negative or neutral effect, thus there is no clear answer regarding this dynamic.

\section{Ties and creativity: The sociological approach}

Following the same line of thinking, the concept of group cohesiveness is also similar to the definition of strong ties in sociological literature. Strong ties among network contacts occur among those with close personal relationships who interact frequently (Granovetter, 1983), like friends, whereas weak ties occur among those who are emotionally more distant from one another.

Most empirical studies about the effect of social processes on creativity have been conducted in the sociology field, in which creativity is not clearly distinguished from innovation. These works usually analyse both creativity at a particular stage or measure both creativity and innovation as the dependent variable in terms of patent counts or citations (Fleming, Mingo \& Chen, 2007; Nerkar \& Paruchuri, 2005). Only a few scholars seek to improve the measurement of creativity using involvement in a creative project (Obstfeld, 2005) or managers' evaluation of submitted ideas (Burt, 2004), but they still consider these measures as measures of success without taking into account that, involvement in creative projects or "good ideas" (according to managers), doesn't necessarily mean "new products". We propose that a process perspective that considers the distinction between creativity (i.e. idea generation) and innovation (i.e. idea implementation) can be useful in explaining the conflicting results in the sociological stream of research.

In this literature, we can find two opposing perspectives about the influence of social structures on creativity. On one side, proponents of cohesion sustain that closed social structures support the development of trust, group norms, and efficient flow of information, all of which enhance creativity (Milliken, Bartel \& Kurtzberg, 2003). These close ties also facilitate the exchange of information that is fine-grained-that is, tacit, complex, or proprietary at both the individual (Obstfeld, 2005; Reagans \& McEvily, 2003) and network levels of analysis (Uzzi \& Spiro, 2005). Research at a dyadic level also shows that strong ties are effective catalysts for creative ideas when such 
ties link actors who are intrinsically motivated to work closely together (Sosa, 2011).

On the other side, proponents of brokerage often build on Granovetter's (1983) concept of the strength of weak ties. Since creativity requires a variety of information sources, a large number of sporadic and distant relationships (i.e., weak ties) can foster creativity (Burt 2004; Nerkar \& Paruchuri, 2005; Perry-Smith \& Shalley, 2003). According to this perspective, people whose networks span structural holes (Burt, 1992) such that they are connected to sources of information that are not connected to each other have early access to diverse, often contradictory information and interpretations, which gives them a competitive advantage in seeing good ideas. In this sense, bridging ties provide access to alternative points of view and to a broader scope than do collocated, or strongly tied, connections. In other words, weak ties help increase creativity and diffuse good ideas once they have been developed. For instance, collaborative brokerage (i.e., low group cohesiveness) can aid in the generation of an idea (i.e. , creativity) but then it can hamper its further diffusion and use by others (Fleming et al., 2007).

In sum, there are reasons to believe that group cohesiveness favours creativity, but it might not directly affect innovation, when innovation is consecutive to creativity.

\section{Our framework of analysis: Group cohesiveness, creativity and innovation}

Thus, adopting a process perspective which sees innovation as an outcome of creativity, we suggest that group cohesiveness (i.e. friendship), group decision-making, and organizational structure affect creativity, while only group decision-making and organizational structure directly affect how creativity lead to implemented innovations. Hence, our premise is that group cohesiveness has only an indirect effect on innovation because innovation is successive to creativity. In other words, friendship has a direct impact on creativity and an indirect impact on innovation, due to the fact that while creativity requires "thinking", implemented innovation requires "action" (Figure 2 summarizes our framework). 


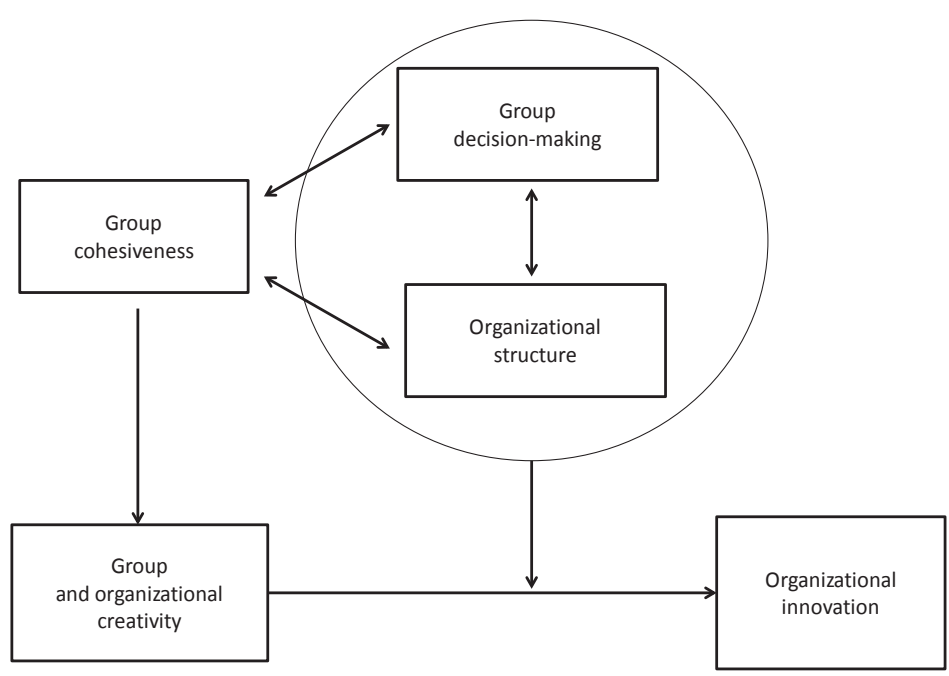

Figure 2. Theoretical framework

\section{CASE STUDY PROCEDURES AND ANALYSIS}

\section{Research strategies: Methodological notes}

A qualitative case study method is adopted in this research. We follow Eisenhardt's (1989) suggestions on case study analysis; they are particularly useful in our research area (Eisenhardt, 1989; Corley \& Gioia, 2004) since using an inductive approach helps us explain the relationships that emerge from the literature review.

As we explained in the introduction, this case is not "unique" nor "exceptional" (Yin, 2013), however given that we have informally followed the story of the venture for several years (since 2003, so even before the firm was established) and we have observed some interesting dynamics that attracted our attention, we choose to formally interview and observe the venture members.

We chose this case because (1) during the period studied (2003-2011), the founding team became more cohesive, allowing us to differentiate the effects of different levels of cohesion (i.e. friendship) over time; (2) the sector in which the firm operates is highly innovative, so creativity is an issue of concern in the firm; and (3) our privileged access to firm members and data.

We collected data about the company from multiple sources: we interviewed the CEO of the firm and integrated that information with data from previous informal interviews with the founding team members; from the company's website and Facebook page; and from other internet sources. 
A visit to the enterprise also allowed us to see their innovations so we could understand the creative process involved. We also held two semi-structured interviews of more than one hour each with key leaders of the firm. All formal interviews, which were carried out between June 2010 and February 2011, were tape-recorded and transcribed, and a summary was sent to the interviewees for review to make sure that we elaborated all the information correctly and to collect further feedbacks and comments.

Our within-case analysis after the data collection (Eisenhardt, 1989) resulted in some speculative research propositions.

In the analysis, we first describe the research site and the main characteristics of the firm. Then, we deepen the investigation on the organizational processes of interest by means of some illustrative events.

\section{Research site: DemoMark}

DemoMark (a pseudonym) is an ICT venture that provides services related to software development. Its activities deal with a wide range of consulting services, such as image processing and assistance with technological transfer from basic research to industry and vice versa.

The entrepreneurial team is composed of four members: Matteo Fris, Roberto Giapani, Ornella Matti, and Sergio Racci (pseudonyms). The firm was established in 2006, but the idea for the firm emerged in 2004/05 when the founders met at the University of Udine, Department of Physics (Table 1 summarises some descriptive information about the founding team members).

Initially, DemoMark provided software solutions for supporting research activities, but its offer has been extended in the face of market changes. Especially during the 2008 world financial crisis, universities and research institutes had financial challenges, so DemoMark started to offer its product to private businesses (software for image enhancement and also websites) as well. Today, DemoMark's software solutions are also applied to medical systems, which are included in some academic research projects. These projects have become increasingly important to the firm over time, especially because thanks to them the firm could develop several new products and logarithms.

At the time of the interviews, members were also considering whether to apply to some public calls. For example, the European Spatial Agency publishes several announcements yearly that could be appropriate for DemoMark's services, but the firm could not afford to apply, as its members would spend too much money and time in writing the project without any assurance that their application would be accepted. 
Table 1. Descriptive information about founding team members

\begin{tabular}{|c|c|c|c|c|}
\hline Name & Matteo Fris & $\begin{array}{l}\text { Roberto } \\
\text { Giapani }\end{array}$ & Ornella Matti & Sergio Racci \\
\hline Year of birth & 1973 & 1970 & 1973 & 1979 \\
\hline Education & $\begin{array}{l}\text { PhD in } \\
\text { Computer } \\
\text { Science }\end{array}$ & $\mathrm{PhD}$ in Physics & $\begin{array}{l}\text { PhD in } \\
\text { Mathematics } \\
\text { and Physics }\end{array}$ & $\begin{array}{l}\text { Master Degree in } \\
\text { Physics } \\
\text { Competencies } \\
\text { on Accounting, } \\
\text { Administration, } \\
\text { Management } \\
\text { and Business } \\
\text { Planning }\end{array}$ \\
\hline $\begin{array}{l}\text { Previous } \\
\text { professional } \\
\text { experience }\end{array}$ & $\begin{array}{l}\text { Post doc } \\
\text { researcher } \\
\text { at the } \\
\text { department } \\
\text { of Physics in } \\
\text { Udine }\end{array}$ & $\begin{array}{l}\text { Post doc } \\
\text { researcher at } \\
\text { the Department } \\
\text { of Physics in } \\
\text { Udine }\end{array}$ & $\begin{array}{l}\text { PhD student at } \\
\text { the Department } \\
\text { of Physics in } \\
\text { Udine; attended } \\
\text { some optional } \\
\text { management } \\
\text { and accounting } \\
\text { university } \\
\text { classes }\end{array}$ & $\begin{array}{l}\text { Master student } \\
\text { in Physics in } \\
\text { Udine }\end{array}$ \\
\hline
\end{tabular}

The external environment and clients' demands have an impact on overall venture creativity and innovation, as information between the client and the firm is exchanged until agreement is reached, at which point most of the creative ideas actually become implemented innovations. Hence, the external context is a stimulus for change and searching for new solutions, which consequently force the founders to work on these inputs. Even if we could not rule out the influence of external dynamics (e.g., the type of demands of clients, etc.) on creative processes, we tried to focus on the number of ideas generated by comparable demands and observed how the process evolved under the situation of low and high group cohesiveness.

DemoMark defines itself as a creative firm. As Sergio Racci explained, "We have several algorithms developed, thanks to all the research projects that could be transformed into products tomorrow. We used only about 30 percent of our algorithms, while the other 70 percent are just good ideas. We don't have enough resources to develop all the potentialities our firm has, or it is difficult to figure out the application of our innovations. For example, we developed software that captures letters and figures: the potential of this innovation is really high. However, the only product we developed was a videocamera that can recognize cars' license plate numbers and automatically send an input to open a gate". 


\section{Members' relationships in DemoMark}

The relationships among the members of this firm evolved over time. In 2002, before the firm was set up, Matteo, Roberto, Sergio, and Ornella met at university. Roberto had a post doc position and was working on some academic projects with Matteo, who was a PhD student. Roberto had been the professor of Sergio, a master's student. Since Sergio was interested in collaborating in a research project, he started to meet Roberto and Matteo more frequently. Ornella, also a master's student, knew Matteo and later took a PhD course in Mathematics and Informatics. When Matteo, Sergio, and Roberto started to talk about setting up an enterprise, they knew little about business planning and administration, so they asked Ornella to help them. She had learned accounting and management in coursework.

\section{Synthesizes the main elements that have changed over time.}

Once the firm was set up, the four founders' relationships strengthened from working together every day, and the group became increasingly cohesive. Thus, their relationship changed over time: from an acquaintance relationship it became friendship, and today two of the founders are married (Ornella and Sergio).

Table 2. Organizational changes at DemoMark

\begin{tabular}{|c|c|c|}
\hline Shifts & $\begin{array}{l}\text { Low Level of Group } \\
\text { Cohesiveness }\end{array}$ & High Level of Group Cohesiveness \\
\hline Governance & $\begin{array}{l}\text { Peer governance: all decisions } \\
\text { made jointly }\end{array}$ & $\begin{array}{l}\text { Operative decisions: made } \\
\text { by whoever has the required } \\
\text { competencies. } \\
\text { Strategic decisions: made jointly }\end{array}$ \\
\hline $\begin{array}{l}\text { Coordination } \\
\text { mechanism }\end{array}$ & $\begin{array}{l}\text { Coordination through } \\
\text { standardization: weekly } \\
\text { meetings defined ex ante } \\
\text { (three times a week) }\end{array}$ & $\begin{array}{l}\text { Coordination through mutual } \\
\text { adjustment: only when necessary }\end{array}$ \\
\hline Trust & $\begin{array}{l}\text { Low level of trust: } \\
\text { acquaintances }\end{array}$ & $\begin{array}{l}\text { High level of trust: friendship (each } \\
\text { member knows that the others } \\
\text { will make the right decisions) }\end{array}$ \\
\hline Clients & $\begin{array}{l}\text { Universities and research } \\
\text { institutes }\end{array}$ & $\begin{array}{l}\text { Universities, research institutes, } \\
\text { and private businesses }\end{array}$ \\
\hline Products & $\begin{array}{l}\text { Software for public research } \\
\text { purposes }\end{array}$ & $\begin{array}{l}\text { Software tailored for private } \\
\text { businesses }\end{array}$ \\
\hline
\end{tabular}

All four of the firm's founders are willing to do what is necessary to make the firm profitable; they have invested time and personal resources in the business and have learned to do what is best for the group, rather than 
only what is best for themselves as individuals. Besides having an impact on creative outcome, this shift was accompanied by changes in the decisionmaking process and the organizational structure.

\section{Group cohesiveness, creativity and innovation: Illustrative concepts}

Three illustrative concepts are described in this section to explore the relationships among cohesiveness, creativity, and innovation: the decisionmaking process, logo and website design, and pride and ethics.

Concept 1: The decision-making process. At the venture's inception, all decisions were made jointly and with unanimity, as the need to control one another's work was considerable. Soon, however, the entrepreneurs faced problems. As Sergio describes it, "In the beginning, when we'd known each other only a short time, we wanted to share everything and discuss every idea. This doesn't mean that we didn't trust each other at the beginning, but we preferred to know and to share all information. Then, day by day, trust among us grew, so now, when someone has to make a decision, we all know that he or she will make the right one." The main inconvenience in the beginning, Sergio explains, was the huge number of interactions required among the four founders: "Think about the purchase of a printer. Even if I knew the prices of two printers, I could not decide which one to buy. I had to email my colleagues and then wait for their answer before making a decision. This took much too long. We noticed that we exchanged a lot of information that wasn't strictly necessary."

The four founders decided to change the internal norms because the increase of the amount of trust needed less control. The increased trust is shown in the number of weekly meetings: in 2006, they met three times a week for about thirty minutes. A year later, they met twice a week, and now they meet only when necessary. The formal mechanisms of control were complemented with trust so they could face the increasing complexity and number of everyday activities.

Today, each member is in charge of activities that are in line with his or her individual knowledge and competencies. Everyone can make decisions that incur an expense of less than 1000 Euros without contacting the others. For strategic decisions, individuals think about solutions without consulting the others, but discuss them together before making the final choice.

While strategic decisions are made jointly, minor decisions are made by the member who is most competent to do so. For example, in the product development process, after the first contact with the client, they decide together who will be in charge of the project, and that person becomes 
responsible for it, talking to the clients and proposing initial ideas and possible solutions to all four members to discuss and decide. Decisions about hiring new employees also follow this rule, where one person does a preselection and all four members make the final decision. While the initial decision-making system led to too much information-sharing and chaos, the combination of collegiality and definition of roles helped to generate new ideas.

As the literature on organisation growth suggests (see for example Churchill \& Lewis, 1983), the efficiency of the decision-making process could be also the result of the growing complexity of the business. This process of growth leads to a structuration of the business, and the definition of roles and responsibilities. In DemoMark this process is also characterised by the strengthening of friends' ties, that consequently, with high probability, affects members' trust.

Concept 2: Logo and website design. At the beginning of the venture, when firm members were thinking about a logo, each member proposed images and ideas. Since this activity has to do with aesthetics and taste, their continuing discussions eventually became an annoyance, and they ended up using an external designer. As Sergio explains, "We discussed a lot about the logo, and in the end, a graphic studio made it. All the discussions were a waste of time, because it was a matter of taste. We would never have found agreement! The same was the case for the website's graphic design-a terrible, exasperating discussion took place until we outsourced the project."

According to Sergio's thinking, it is important to discuss and decide jointly technical decisions that affect the firm's products and activities and when certain competencies and kinds of knowledge are necessary. Only then can the discussion lead to the generation of new ideas of which the members can take advantage. However, under some conditions debate is a waste of time. The problems associated with agreeing on logo and website design show how a low level of group cohesiveness can limit creativity (and, consequently, innovation) in a small firm where there are not many slack resources.

Concept 3: Pride and ethics. Organizational culture, particularly ethics, has affected the firm's strategy. When the members decided to begin the enterprise, they decided not to be a university spin-off because they did not want to have academic staff on their board. They wanted to be completely independent, without owing anything to anyone.

Both pride and ethics are important to them. For example, they agreed when they started the firm that they would "never do websites" because it is as a low-level activity and that they would "never develop software for military purposes," which would be against their moral principles. They also 
decided they would have help research in some branches of biology, such as those that control the intensity of X-rays, in order to avoid having to take responsibility for a possible mistake in the software. They also added in the certificate of incorporation some notes about ethical behaviour and choices.

However, after the world financial crisis in 2008, they had to disregard some of their initial agreements even though doing so was contrary to their principles. For instance, they developed some websites, but their norms and values prevented them from developing some ideas into innovations, although they were aware of the potential applications of their products. Since the firm members know each other well, they discuss possible new applications and products informally.

The moral and ethic norms they stated at the beginning are examples of factors that prevent creativity from becoming innovation. In a boarder interpretation, we could say that in some cases, contextual factors sometimes prevent creativity from becoming innovation. However, this perception need to be further analysed to be consistent.

\section{CASE ANALYSIS AND PROPOSITIONS}

It appears that group processes and context can be either the main drivers of creative outcomes or the main obstacles. By analysing the shifts and events in this particular case study, we explored how the creative and innovative outcome of a small firm, DemoMark, is affected by group cohesiveness and how the organizational structure and the decision-making norms influence the process that generates the new ideas (i.e., creativity) that lead to innovation.

Single elements like group cohesiveness, decision-making processes, information flow, and organizational context can have positive, neutral, or negative effects on creativity over time. These factors also appear to have differing impacts on innovation.

When the relationships among the members of the firm seem to shift from a low level to a high level of group cohesiveness, creativity also reaches higher levels. This observation is in accordance with social capital theories that suggest that closed social structures increase trust, ease the development of group norms, and improve information flow, all of which enhance creativity (Milliken et al., 2003; Coleman, 1988; Sosa, 2011). This effect is especially evident in the process of new product development (Concept 1), even when one person is responsible for the project, if all the members debate the various solutions, examine the various points of view, and deliberate the final solution with the richness of information matured in this process. 
This sharing of ideas fosters the creative outcome, but our case shows that cohesive groups can generate new ideas without necessarily implementing them, since implementation may require resources that a small firm cannot afford because of resource constraints or ethical issues (Concept 3). In fact, DemoMark's CEO declares that only about 30 percent of the firm's creative ideas become products.

A low level of group cohesiveness and the related emphasis on consensus and unanimity endangered creativity in DemoMark's early days, as discussing everything became tiresome in time (Concept 2). However, according to the brokerage in social capital theory (Burt 2004), a low level of group cohesiveness and a large amount of information-sharing should have been the key for creativity. Coming from different information groups, the members should have brought together their differing perspectives, which should have engendered creativity. In this case, we found not only that a low level of group cohesiveness is not sufficient for the generation of new ideas, but that it can also be an obstacle to innovation. The need for control over one another's work and the common objective to make the firm profitable caused an information overload related to ongoing activities, which consumed the time and resources that were needed for the development of new ideas.

It appears also that the exchange of thoughts in a highly cohesive group that can divide labour efficiently is a valuable resource for social capital and, therefore, for creative and innovative performance. Since members discuss new ideas from the beginning and consider how to organize the potential project, there is a sense of group ownership that makes the group more likely to implement the project and reach the innovation stage.

Another element to consider in this process is the small firm's limited resources, especially money and time, which limits its ability to develop innovative projects. Instead of using its own resources, the firm uses its relationships with clients as a source of ideas and money necessary for innovation. In this case, the number of good ideas is higher than the number of products that are developed, so size is a critical element of the dynamic.

The organizational culture-particularly the ethical norms that characterize DemoMark's culture-and the members' sense of pride are also important factors in the firm's creative process (Concept 3). Previous research finds that the ego can be a factor in generating new ideas during brainstorming sessions (Cohen, Whitmyre \& Funk, 1960). Strong shared norms based on personal values and mutual respect could limit the development of innovation (e.g., software for military uses), even if such shared norms do not obstruct the generation of ideas. In fact, the four founders agreed to bypass some of the proscriptions they set when they founded the business, such as the proscription against building websites. Clearly, ideas are present even 
when the group's morals, values, and principles preclude them from pursuing these ideas. The choice not to build websites was due to pride, so it was easier to overcome than an ethical proscription would have been.

Concepts 1, 2, and 3 illustrate how group cohesiveness interacts with group processes and contextual factors to generate creativity and the succeeding innovative outputs. A low level of group cohesiveness, combined with a highly formalized-decision making processes, results in a low level of creativity and, thus, a low level of innovation. Organizational context does not appear to play a critical role in this relationship. However, a high level of cohesion leads to creativity and the generation of ideas, as strong ties facilitate information flows and informal decision-making processes based on trust. In this case, organizational context plays a critical role in transforming ideas into products, while resource constraints and ethical norms prevent creativity from leading to innovation. In short:

Proposition 1a. A low level of group cohesiveness in the founding team causes; disorganization in the management of activities, greater need for control over other members' work, information overload, and a low sense of group ownership of the initial idea, resulting in a low level of creativity and, consequently, a low level of innovation.

Proposition 1b. A high level of group cohesiveness in the founding team helps the team define the internal division of labour and lowers the need for control over other members' work, fostering creativity, increasing the sense of group ownership of the initial idea, and increasing innovation.

Proposition 2a. Limited resources interfere with the mechanisms of generating innovation, but not of group creativity.

Proposition 2b. Group members' pride and ethical norms interfere with the mechanism of generating innovation, but not that of creativity. As an obstacle to innovation, pride is weaker than ethics.

\section{CONCLUSION}

In this article, by reviewing several research traditions about the role of amical relationships, we focused on how friendship and business norms may be seen as opposite forces that push firm decision-makers to think and act in different ways.

This exploratory research aims to shed light on friendship as an important group process that deserves more attention in an effort to go beyond the recurrent theme that founding groups become more structured over time (Kohtamäki, Kekäle \& Viitala, 2004). As propositions $1 \mathrm{a}$ and $1 \mathrm{~b}$ aim to stress, we focus on a specific group characteristic related to friendship, that is group 
cohesiveness, and determine its impact on two consecutive outcomes, creativity and innovation. By analysing the DemoMark case, we begin to shed light on the possible interrelationships among disciplines in explaining the impact of group processes on creativity and innovation. Since the case focuses on a small entrepreneurial venture, it provides useful insights that differ from the existing research conducted in larger settings (Bergendahl \& Magnusson, 2014).

In particular, our findings from this exploratory case study show that the principle of reciprocity by regulating both business and friendship may differently impact on the way the founding team members take decisions and thus on firm level structure and outcomes. Indeed, members perceived their thoughts (i.e. opinions) as a resource for the business. The high reciprocity that characterizes business dynamics implied that all resources, even thoughts, had to be equally exchanged. In other words, the prevalence of the exchange-oriented norms in place enhanced the need for exchanging all thoughts. That's why a situation of low group cohesiveness (i.e. friendship) may lead to disorganization: it appears that, in this case, chaos did not lead to creativity or innovation. While high group cohesiveness, which provides the benefit of lowering the perceived need of full reciprocity in exchanges within the firm, favors the creation of structure in the organization which sustains the generation of both creative ideas and implemented innovation.

The literature on founding teams (Cesaroni et al., 2005) may benefit from this research, which provides new insights on group dynamics, as requested in a recent call for research on the relationships between entrepreneurial teams' group dynamics and innovative processes (Baron \& Tang, 2011; Brockman et al., 2010).

As for practical implications, we hope that this exploratory research stimulates further investigations in this area, in particular scholars might consider the issue of exchanges and reciprocity introduced in the theoretical part of the article, and develop a finer grained research model to purposefully collect data to explore how business and friendship exchanges interact. We report in the Appendix a list of references of commonly used measures of friendship that researchers might want to consider in their future analysis. For instance, it would be interesting to explore how the different reciprocity principles that regulate business and friendship dynamics impact on firm level outcome (such as business performance, growth, etc.) and on individuals (e.g., happiness, life and work satisfaction, etc.). Also, the theoretical ideas about reciprocity might be used to analyse other group decision-making processes. Moreover, not only scholars, but also entrepreneurs, may certainly benefit from the explanation of what can affect creativity and innovation and the possible consequences of internal processes, and its effect on other firm 
outcomes. For their part, educators could learn to increase their focus on those actions and behaviours that foster not only creativity but also tangible outcomes such as innovation.

The main limitations of this study lie in the implementation of the case study research method. A multiple case study with purposefully collected data could be more useful in defining the role of friendship in innovative outcomes. For instance, a case in which the founding team was initially made up of a group of friends but in which relationships evolved such that each member became more isolated in making decisions could help this work to advance. Also, a more refined assessment of friendship in business settings is certainly a challenging task that deserves further investigation. Moreover, a configurational approach could suggest new insights on the intervening factors that lead to creativity and innovation, especially in terms of differentiating how organizational and group characteristics work together to lead to creative and innovative outcomes. Finally, as the present research involves an inductive case study, future quantitative studies could come up with other propositions in order to advance knowledge about the relationships between friendship and business also focusing on creativity and innovation.

\section{References}

Adams, R.G., \& Blieszner, R. (1994). An integrative conceptual framework for friendship research. Journal of Social and Personal Relationships, 11(2), 163-184.

Allan, G. A. (1989) Friendship: Developing a sociological perspective. Boulder: Westview Press.

Amabile, T.M., Conti, R., Coon, H., Lazenby, J., \& Herron, M. (1996). Assessing the work environment for creativity. Academy of Management Journal, 39(5), 1154-1184.

Amason, A.C., \& Sapienza, H.J. (1997). The effects of top management team size and interaction norms on cognitive and affective conflict. Journal of Management, 23(4), 495-516.

Anderson, N., \& King, N. (1993) Innovation in organizations. In C.L. Cooper \& I.T. Robertson (Eds.), International Review of Industrial and Organizational Psychology Vol. 8 (pp.1-34). Chichester: Wiley.

Baron, R.A., \& Tang, J. (2011). The role of entrepreneurs in firm-level innovation: Joint effects of positive affect, creativity, and environmental dynamism. Journal of Business Venturing, 26(1), 49-60.

Baumeister, R.F., \& Leary, M.R. (1995). The need to belong: Desire for interpersonal attachments as a fundamental human motivation. Psychological Bulletin, 11(3), 497-529. 
Bergendahl, M., \& Magnusson, M. (2014). Combining collaboration and competition: A key to improved idea management? European Journal of International Management, 8(5), 528-547.

Berndt, T.J., \& McCandless, M.A. (2009). Methods for investigating children's relationships with friends. In K. H. Rubin, W. M. Bukowski \& B. Laursen (Eds.), Handbook of Peer Interactions, Relationships, and Groups (pp. 63-81). New York: Guilford.

Blieszner, R., \& Adams, R. G. (1992). Adult Friendship (Vol. 3). Newbury Park, CA: Sage Publications.

Brockman, B.K., Rawlston, M.E., Jones, M.A., \& Halstead, D. (2010). An exploratory model of interpersonal cohesiveness in new product development teams. Journal of Product Innovation Management, 27(2), 201-219.

Burt, R. (1992). Structural Holes: The Structure of Social Capital Competition. Cambridge, MA: Harvard University Press.

Burt, R.S. (2004). Structural holes and good ideas. American Journal of Sociology, 110(2), 349-399.

Cesaroni, F., Minin, A.D., \& Piccaluga, A. (2005). Exploration and exploitation strategies in industrial R\&D, Creativity and Innovation Management, 14(3), 222-232.

Chen, M. H. (2007). Entrepreneurial leadership and new ventures: Creativity in entrepreneurial teams. Creativity and Innovation Management, 16(3), 239-249.

Churchill, N. C., \& Lewis, V. L. (1983). The five stages of small business growth. Harvard Business Review, 61(3), 30-50.

Coase, R. H. (1937). The nature of the firm. Economica, 4(16), 386-405.

Cohen, D., Whitmyre, J.W., \& Funk, W.H. (1960). Effect of group cohesiveness and training upon creative thinking. Journal of Applied Psychology, 44(5), 319-322.

Coleman, J. S. (1988). Social capital in the creation of human capital. American Journal of Sociology, 94, S95-S120.

Collins, A., \& van Dulmen, M. (2006). Friendships and Romance in Emerging Adulthood: Assessing Distinctiveness in Close Relationships. In A.J. Jensen \& T.J. Lynn (Eds.), Emerging Adults in America: Coming of Age in the 21st Century (pp. 219-234). Washington, DC: American Psychological Association.

Corley, K.G., \& Gioia, D.A. (2004). Identity ambiguity and change in the wake of a corporate spin-off. Administrative Science Quarterly, 49(2), 173-208.

Corte, U. (2013). A Refinement of Collaborative Circles Theory Resource Mobilization and Innovation in an Emerging Sport. Social psychology quarterly, 76(1), 25-51.

Craig, T.Y., \& Kelly, J.R. (1999). Group cohesiveness and creative performance. Group Dynamics: Theory, Research, and Practice, 3(4), 243-256. 
Crossan, M.M., \& Apaydin, M. (2010). A multi-dimensional framework of organizational innovation: A systematic review of the literature. Journal of Management Studies, 47(6), 1154-1191.

De Massis, A., Frattini, F., \& Lichtenthaler, U. (2013). Research on technological innovation in family firms: Present debates and future directions. Family Business Review, 26(1), 10-31.

Demir, M., \& Davidson, I. (2013). Toward a better understanding of the relationship between friendship and happiness: Perceived responses to capitalization attempts, feelings of mattering, and satisfaction of basic psychological needs in same-sex best friendships as predictors of happiness, Journal of Happiness Studies, 14(2), 525-550.

Demir, M., Özen, A., \& Procsal, A. (2014). Friendship and happiness. In A. Michalos (Ed.), Encyclopedia of Quality of Life and Well-Being Research (pp. 2359-2364). Berlin: Springer.

Demır, M., \& Weitekamp, L. A. (2007). I am so happy 'cause today I found my friend: Friendship and personality as predictors of happiness. Journal of Happiness Studies, 8(2), 181-211.

Diehl, M., \& Stroebe, W. (1987). Productivity loss in brainstorming groups: Toward the solution of a riddle, Journal of Personality and Social Psychology, 53(3), 497-509.

Eisenhardt, K.M. (1989). Building theories from case study research. Academy of Management Review, 14(4), 532-550.

Farrell, M. (2001). Collaborative circles. Friendship Dynamics and Creative Work. Chicago: The University of Chicago Press.

Festinger, L. (1950). Informal social communication. Psychological Review, 57(5), 271-282.

Fleming, L., Mingo, S., \& Chen, D. (2007). Collaborative brokerage, generative creativity, and creative success. Administrative Science Quarterly, 52(3), 443-475.

Ford, C.M. (1996). A theory of individual creative action in multiple social domains. Academy of Management Review, 21(4), 1112-1142.

Foa, U. G. (1973). Interpersonal and Economic Resources. Science, 171(3969), 345-351.

Furman, W., \& Buhrmester, D. (1985). Children's perceptions of the personal relationships in their social networks. Developmental Psychology, 21(6), 1016-1024.

Granovetter, M. (1983). The strength of weak ties: A network theory revisited. Sociological Theory, 1(1), 201-233.

Harvey, S. (2013). A different perspective: The multiple effects of deep level diversity on group creativity. Journal of Experimental Social Psychology, 49(5), 822-832.

Hayes, S., (2014). Creative synthesis: Exploring the process of extraordinary group creativity. The Academy of Management Review, 39(3), 324-343. 
Hays, R. B. (1988). Friendship. In S. W. Duck (Ed.), Handbook of Personal Relationships: Theory, Research, and Interventions (pp. 391-408). New York: Wiley.

Hemlin, S. (2009). Creative knowledge environments: An interview study with group members and group leaders of university and industry R\&D groups in biotechnology. Creativity and Innovation Management, 18(4), 278-285.

Hendrick, S. S. (1988). A generic measure of relationship satisfaction. Journal of Marriage and the Family, 50(1), 93-98.

Hoegl, M., \& Gemuenden, H.G. (2001). Teamwork quality and the success of innovative projects: A theoretical concept and empirical evidence. Organization Science, 12(4), 435-449.

Hoegl, M., Gibbert, M., \& Mazursky, D. (2008). Financial constraints in innovation projects: When is less more? Research Policy, 37(8), 1382-1391.

Hogg, M.A., Fielding, K.S., Johnson, D., Masser, B., Russell, E., \& Svensson, A. (2006). Demographic category membership and leadership in small groups: A social identity analysis. The Leadership Quarterly, 17(4), 335-350.

Hogg, M.A., \& Hains, S.C. (1998). Friendship and group identification: A new look at the role of cohesiveness in groupthink. European Journal of Social Psychology, 28(3), 323-341.

Hülsheger, U.R., Anderson, N., \& Salgado, J.F. (2009). Team-level predictors of innovation at work: A comprehensive meta-analysis spanning three decades of research. Journal of Applied Psychology, 94(5), 1128-1137.

Kammerlander, N., Dessì, C., Bird, M., Floris, M., \& Murru, A. (2015). The impact of shared stories on family firm innovation: A multicase study. Family Business Review, 28(4), 332-354.

Klotz, A.C., Hmieleski, K.M., Bradley, B.H., \& Busenitz, L.W. (2014). New venture teams: A review of the literature and roadmap for future research. Journal of Management, 40(1), 226-255.

Kohtamäki, M., Kekäle, T., \& Viitala, R. (2004). Trust and innovation: From spin-off idea to stock exchange. Creativity and Innovation Management, 13(2), 75-88.

Jensen, M. C., \& Meckling, W. H. (1976). Theory of the firm: Managerial behavior, agency costs and ownership structure. Journal of Financial Economics, 3(4), 305-360.

Laursen, B. (1993). Conflict management among close peers. New Directions for Child and Adolescent Development, 60, 39-54.

Levine, J.M., \& Moreland, R.L. (2004). Collaboration: The social context of theory development, Personality and Social Psychology Review, 8(2), 164-172.

Mendelson, M. J., \& Aboud, F. (1999). Measuring friendship quality in late adolescents and young adults: McGill friendship questionnaires. Canadian Journal of Behavioural Science, 31(2), 130-132.

Milliken, F.J., Bartel, C.A., \& Kurtzberg, T.R. (2003). Diversity and creativity in work groups: A dynamic perspective on the affective and cognitive 
processes that link diversity and performance. In P.B. Paulus \& B.A. Nijstad (Eds.), Group Creativity: Innovation through Collaboration (pp. 32-62). New York: Oxford University Press.

Morry, M. M. (2003). Perceived locus of control and satisfaction in same-sex friendships. Personal Relationships, 10(4), 495-509.

Mudrack, P.E. (1989). Defining group cohesiveness a legacy of confusion? Small Group Research, 20(1), 37-49.

Mullen, B., \& Copper, C. (1994). The relation between group cohesiveness and performance: An integration. Psychological Bulletin, 115(2), 210.

Nerkar, A., \& Paruchuri, S. (2005). Evolution of R\&D capabilities: The role of knowledge networks within a firm. Management Science, 51(5), 771-785.

Obstfeld, D. (2005). Social networks, the tertius iungens orientation, and involvement in innovation. Administrative Science Quarterly, 50(1), 100-130.

Parker, J.G., \& Asher, S.R. (1987). Peer relations and later personal adjustment: Are low accepted children "at risk"? Psychological Bullettin, 102(3), 357-389.

Paulus, P. B., \& Yang, H. (2000). Idea generation in groups: A basis for creativity in organizations. Organizational Behavior and Human Decision Processes, 82, 76-87.

Perry-Smith, J.E., \& Shalley, C.E. (2003). The social side of creativity: A static and dynamic social network perspective. Academy of Management Review, 28(1), 89-106.

Rank, J., Pace, V.L., \& Frese, M. (2004). Three avenues for future research on creativity, innovation, and initiative. Applied Psychology, 53(4), 518-528.

Reagans, R., \& McEvily, B. (2003). Network structure and knowledge transfer: The effects of cohesion and range. Administrative Science Quarterly, $48(2), 240-267$.

Ross, W. D. (1925). The Oxford Translation of Aristotle. Vol. IX: The Nichomachean Ethics. London: Oxford University Press.

Sarooghi, H., Libaers, D., \& Burkemper, A. (2015). Examining the relationship between creativity and innovation: A meta-analysis of organizational, cultural, and environmental factors. Journal of Business Venturing, 30(5), 714-731.

Shalley, C.E. (1991). Effects of productivity goals, creativity goals, and personal discretion on individual creativity. Journal of Applied Psychology, 76(2), 179.

Solano, C. H. (1986). People without friends: Loneliness and its alternatives. In V. J. Derlega \& B. A. Winstead (Eds.), Friendship and Social Interaction (pp. 227-246). New York: Springer Verlag.

Sosa, M.E. (2011). Where do creative interactions come from? The role of tie content and social networks. Organization Science, 22(1), 1-21.

Starko, A. J. (2013). Creativity in the Classroom: Schools of Curious Delight. USA: Routledge.

Sullivan, H.S. (1953). The Interpersonal Theory of Psychiatry. New York: Norton. 
Uzzi, B. \& Spiro, J. (2005). Collaboration and creativity: The small world problem. American Journal of Sociology, 111(2), 447-504.

West, M. A. (2002). Sparkling fountains or stagnant ponds: An integrative model of creativity and innovation implementation in work groups. Applied Psychology: An International Review, 51(3), 355-387.

Williams, W., \& Yang, L. (1999). Organizational creativity. In R. J. Sternberg (Ed.), Handbook of Creativity (pp. 373-391). New York: Cambridge University Press.

Woodman, R.W., Sawyer, J.E., \& Griffin, R.W. (1993). Toward a theory of organizational creativity. Academy of Management Review, 18(2), 293321.

Yin, R. K. (2013). Case Study Research: Design and Methods. Thousand Oaks, CA: Sage Publications.

\section{Appendix}

A summary of different measures of friendship from the literature

\begin{tabular}{lll}
\hline $\begin{array}{l}\text { Measures that consider } \\
\text { positive and negative } \\
\text { components of } \\
\text { friendship }\end{array}$ & $\begin{array}{l}\text { a. Network of Relationships } \\
\text { Inventory (NRI) }\end{array}$ & Furman \& Buhrmester, 1985* \\
& $\begin{array}{l}\text { b. McGill Friendship } \\
\text { Questionnaire- Friend's } \\
\text { Functions (MFQ-FF) }\end{array}$ & Mendelson \& Aboud, 1999* \\
\hline Quantity of friendship & $\begin{array}{l}\text { a. Single item, which asks } \\
\text { participants to report their } \\
\text { number of close friends }\end{array}$ & Demir \& Weitekamp, 2007* \\
& $\begin{array}{l}\text { b. Combined with quality } \\
\text { a. Single item }\end{array}$ & Demir et al., 2013* \\
\hline $\begin{array}{l}\text { Satisfaction with } \\
\text { friends }\end{array}$ & $\begin{array}{l}\text { b. Scale adapted from } \\
\text { Hendricks's (1988*) }\end{array}$ & Morry, 2003* \\
\hline
\end{tabular}

* Note: articles indicated in the reference list.

\section{Abstract (in Polish)}

Z perspektywy procesu wywodzqcego się z kilku dyscyplin, dyskutujemy teoretycznie o tym, jak dynamika przyjaźni w zespołach założycielskich może wpłynqú na firmę. Opracowujemy konceptualny model, który uwzględnia odmienna naturę wymiany w biznesie i przyjaźni, co może posłużyć za użyteczna podstawę dla przyszłych badań (w załączniku przedstawiamy kilka miar przyjaźni). Następnie badamy przykładowy przypadek. Skupiamy się na spójności grup (pełnomocnictwa do 
przyjaźni), podejmowaniu decyzji i organizacji zespołu założycielskiego włoskiej firmy technologicznej oraz poznajemy proces generowania twórczych pomysłów i wdrażania innowacji. Nasze wstępne ustalenia wskazuja, że chaos niekoniecznie sprzyja kreatywności i innowacji: przy niskiej spójności grupowej prowadzi do dezorganizacji, ponieważ normy biznesowe przeważajq nad przyjaźniq, wysoka spójność grup tworzy strukturę organizacyjnq, która podtrzymuje generowanie kreatywnych efektów, wzmacniajqc rolę przyjaźni w procesie decyzyjnym. Tłumaczymy to stwierdzenie w świetle zasady wzajemności wymiany. Słowa kluczowe: spin-offs; wzajemność; przyjaźń; spójność grup; kreatywność; innowacja.

\section{Biographical notes}

Alessandra Tognazzo is a Post-Doc Researcher at the Department of Economics and Management at the University of Padova, where she received her Ph.D. in 2012. She is professor of Family Business in Padova. In 2010 she was visiting Ph.D. at the Master in Research in Management, IESE Business School, in Barcelona. She received several research awards. Her work has been focusing on entrepreneurship and SMEs. She is currently publishing her works in leadership, family business and entrepreneurship international journals. Corresponding with the author: alessandra.tognazzo@unipd.it University of Padova, Department of Economics "Marco Fanno", Via del Santo 33, Padova, I-35123.

Paola Angela Maria Mazzurana is a Post-Doc Researcher and adjunct professor of Organization Studies at the Department of Economics and Statistics, University of Udine. She received her Ph.D. in 2010. In 2009 she was visiting $\mathrm{PhD}$ at the Department of Organisation at the Copenhagen Business School. Her research interests focus on the governance of interorganizational relationships, management and growth patterns in SMEs. Contact information: paola.mazzurana@uniud.it University of Udine, Department of Economics and Statistics, Via Tomadini 30/a, Udine, I-33100. 
